This is the author's final, peer-reviewed manuscript as accepted for publication. The publisher-formatted version may be available through the publisher's web site or your institution's library.

\title{
Agronomic comparison of anhydrous ammonia applied with a high speed-low draft opener and conventional knife injection in corn
}

Krishna P. Woli, Fabián G. Fernández, John E. Sawyer, Joshua D. Stamper, David B. Mengel, Daniel W. Barker, and Mark H. Hanna

\section{How to cite this manuscript}

If you make reference to this version of the manuscript, use the following information:

Woli. K. P., Fernández, F. G., Sawyer, J. E., Stamper, J. D., Mengel, D. B., Barker, D. W., \& Hanna, M. H. (2014). Agronomic comparison of anhydrous ammonia applied with a high speed-low draft opener and conventional knife injection in corn. Retrieved from http://krex.ksu.edu

\section{Published Version Information}

Citation: Woli. K. P., Fernández, F. G., Sawyer, J. E., Stamper, J. D., Mengel, D. B., Barker, D. W., \& Hanna, M. H. (2014). Agronomic comparison of anhydrous ammonia applied with a high speed-low draft opener and conventional knife injection in corn. Agronomy Journal, 106(3), 881-892.

Copyright: Copyright (C) 2014 by the American Society of Agronomy

Digital Object Identifier (DOI): doi:10.2134/agronj13.0441

Publisher's Link: https://www.agronomy.org/publications/aj/articles/106/3/881

This item was retrieved from the K-State Research Exchange (K-REx), the institutional repository of Kansas State University. K-REx is available at http://krex.ksu.edu 


\title{
Agronomic Comparison of Anhydrous Ammonia Applied with a High Speed- Low Draft Opener and Conventional Knife Injection in Corn
}

\author{
Krishna P. Woli*, Fabián G. Fernández, John E. Sawyer, Joshua D. Stamper, David B. Mengel, Daniel W. Barker, \\ and Mark H. Hanna
}

\begin{abstract}
Anhydrous ammonia (AA) is an important $\mathrm{N}$ fertilizer in the U.S., and with large farming operations rapid application is needed. This study evaluated the impact of AA application timing and $\mathrm{N}$ rates when applied with a high speed low draft (HSLD) or a conventional till knife (CTKI) on corn (Zea Mays L.) production in no-tillage fields. The study was conducted at sites located in Illinois, Iowa, and Kansas from 2007 to 2009. The experimental design was a split-plot factorial arrangement of application method, timing (fall; spring preplant, SP; and sidedress, SD), and five $\mathrm{N}$ rates. Fall AA application was least efficient (mean $55 \mathrm{~kg} \mathrm{~N}^{-1}$ higher optimum $\mathrm{N}$ and $2 \%$ lower grain yield, GY), with SP and SD equivalent. The HSLD was comparable to the CTKI with most applications, except when high $\mathrm{N}$ rates (180 and $225 \mathrm{~kg} \mathrm{~N} \mathrm{ha}^{-1}$ ) were applied SP. For these treatments AA injury reduced plant population (PP), early season growth, canopy NDVI, and GY. Seedling injury did not occur with any N rate or timing with the CTKI. Shallow AA placement at high speed with the HSLD can provide a viable alternative to traditional deeper knife injection when conditions are suitable for AA application and positioning avoids corn seedling injury. Anhydrous ammonia application with the HSLD, however, should be avoided where high SP AA rates may be placed directly under future corn rows.
\end{abstract}

Abbreviations: AA, anhydrous ammonia; AONR, agronomic optimum nitrogen rate; CTKI, conventional till knife injection system; GY, grain yield; HSLD, high speed-low draft opener 
system; NDVI, normalized difference vegetative index; PP, plant population; RCM, relative chlorophyll meter; RPP, relative plant population; SD, sidedress; SP, spring preplant.

Nitrogen fertilizer is needed to maximize profitability in many corn fields. Of many different sources of N available to U.S. farmers, AA is generally readily available and the least expensive source of $\mathrm{N}$ fertilizer, has the most concentrated analysis at $82 \% \mathrm{~N}$, and is more slowly converted to nitrate than other $\mathrm{N}$ fertilizers (Fernández et al., 2009). It can be applied in the fall following harvest, in the spring prior to seeding, or sidedress during the growing season. Different application timings, however, may impact its efficiency and corn production.

Injecting AA below the soil surface is required to avoid volatile losses during application. The traditional injection system in use for many years has been a shank and knife system, with an outlet at the bottom sides of a delivery tube behind the knife (Blue and Eno, 1954). The injection requirement can result in higher corn GY compared to surface applied urea or ureaammonium nitrate solution in no-tillage and high crop residue levels (Mengel et al., 1982). However, anhydrous ammonia requires specialized and expensive storage facilities, and transport and application equipment (Schmitt and Rehm, 1993). These requirements can sometimes constrain dealer storage capacity and overall AA supply at critical application times. To spread out workloads and to more effectively utilize favorable conditions farmers desire to apply AA in the fall to avoid the busy spring planting season (Bundy, 1986; Randall and Schmitt, 1998; Kyveryga et al., 2004). An alternative would be to increase capacity by increasing speed of application, which would decrease springtime application-days and labor requirements, but would increase critical AA supply need. 
Although spring preplant (SP) and SD application of AA is generally most efficient because the application is closer to peak crop demand (Smith, 1966), late fall application of AA is practiced in the northern U.S. where soil temperatures result in slower conversion of AA to nitrate and where precipitation patterns lower potential for nitrate losses. Randall and Sawyer (2008) estimated that $25 \%$ of the corn acreage across the Corn Belt receives fall applied N. However, risk of $\mathrm{N}$ loss from fall applications are greater than SP or SD because losses increase with the length of time between when applied and when needed by the plant (Chalk et al., 1975). This N loss can also result in reduced GY relative to spring applications (Bundy, 1986; Randall and Sawyer, 2008; Miller et al., 2011). A nitrification inhibitor, like nitrapyrin [2-chloro-6(trichloromethyl)pyridine], can increase $\mathrm{N}$ use efficiency by delaying conversion of ammonium to nitrate when loss conditions occur (Hoeft, 1984; Shi and Norton, 2000; Randall et al., 2003). However, the use of nitrification inhibitors with fall applied AA has produced inconsistent results (Boswell, 1977; Hendrickson et al., 1978; Blackmer and Sanchez, 1988; Randall and Sawyer, 2008).

At the time of application, excessive ammonia movement from the injection point can result in loss of AA from soil and toxicity damage to corn seedlings and roots. Ammonia movement from the injection point increases in soils with low moisture, low organic matter, and coarse textures (Papendick and Parr, 1966; Parr and Papendick, 1966; Schmitt and Rehm, 1993). Also, physical disruption from injection knives, such as large voids in dry cloddy soil or smearing of the injection track in overly wet soils, can create zones that allow ammonia movement toward the soil surface (Stanley and Smith, 1956; Overdahl and Rehm, 1990). Conversely, retention of AA can generally be enhanced with lower $\mathrm{N}$ rates, deeper injection, and narrower injection spacing (McDowell and Smith, 1958). 
Reducing the injection depth would reduce tractor power requirements and allow greater application speeds. This would also increase field application capacity and require less fuel, but would be an advantage only if ammonia losses are held to acceptable levels (Hanna et al., 2005). Also, reducing injection depth would increase the chance for corn seedlings and roots to be near or in the ammonia injection zone, which would increase potential for seed/seedling toxicity and thus make shallow injection more problematic (Cooke, 1962; Swart et al., 1971; Overdahl and Rehm, 1990; Fujinuma et al., 2011). Blue and Eno (1954) found injected ammonia to be concentrated in zones from 5 to $20 \mathrm{~cm}$ in width, depending on soil moisture content. Most ammonia was retained within an 8-cm zone of the injection point.

As farm size increases there is a need to increase the speed of $\mathrm{N}$ application without sacrificing $\mathrm{N}$ use efficiency. New applicators have been developed that inject AA using a large coulter wheel to open the soil and place AA into the soil, and with an offset closing wheel to close the injection track. These application tools operate at a shallower depth, requiring less draft power and causing less surface disturbance (Hanna et al., 2005). Decreased surface soil disturbance would be helpful in maintaining surface residue for erosion control in no-tillage systems. With the desire to reduce environmental degradation related to nitrate leaching and improve $\mathrm{N}$ use efficiency, increased speed of AA application at SP and SD would allow movement away from fall application. While such AA equipment has been commercially developed, research on crop response following AA application is lacking. The objectives of this study were to compare agronomic performance of AA application with a proprietary, shallow placement, low soil disturbance opener system to a conventional knife injection system. 


\section{MATERIALS AND METHODS}

\section{Study Site Characteristics}

The study was conducted for three years (2007-2009) in three locations: University of Illinois Research and Education Center at Champaign, IL ( $\left.40^{\circ} 5^{\prime} 27.78^{\prime \prime} \mathrm{N}, 88^{\circ} 13^{\prime} 38.48^{\prime \prime} \mathrm{W}\right)$; Iowa State University Agronomy and Agricultural Engineering Research Farm, near Boone, IA (42 $00^{\prime} 37^{\prime \prime} \mathrm{N}, 93^{\circ} 44^{\prime} 32^{\prime \prime} \mathrm{W}$ ); and near Kansas State University on cooperating private farms near Willard, KS $\left(39^{\circ} 5^{\prime} 36^{\prime \prime} \mathrm{N}, 95^{\circ} 56^{\prime} 27^{\prime \prime} \mathrm{W}\right)$ in 2007 and near Silver Lake, KS (39 5' 52”N, $95^{\circ}$ 49'33”W) in 2008 and 2009. Table 1 summarizes the geographic sites and predominant soils. The soils ranged from loam to silty clay loam surface textures.

At each site, soil samples were collected before treatment application from the $0-15$ or $0-20$ $\mathrm{cm}$ depth, air-dried, ground, and used to determine routine soil tests (Table 1). Soil $\mathrm{NO}_{3}-\mathrm{N}$ was determined on soil samples collected at SP before treatment application at Illinois sites, $0-30 \mathrm{~cm}$ depth; early June from control plots at Iowa sites, 0-30 cm depth; and before treatment application spring (2007) or fall (2007 and 2008) at Kansas sites, 0-60 cm depth (Table 1). For all soil samples, composite samples were collected per replicate: Illinois, five cores; Iowa, twelve cores; and Kansas, fifteen cores. Routine soil analyses were conducted using recommended procedures for the North-Central Region (Brown, 1998). When P and K soil test levels were found to be deficient using the individual state soil test calibrations, recommended $\mathrm{P}$ or $\mathrm{K}$ rates were applied prior to planting. At the Iowa site in 2008, triple superphosphate fertilizer was broadcast applied in the spring at $37 \mathrm{~kg} \mathrm{P} \mathrm{ha}^{-1}$. At the Kansas site in 2007, $60 \mathrm{~kg} \mathrm{P}$ $\mathrm{ha}^{-1}$ as monoammonium phosphate (supplied $12 \mathrm{~kg} \mathrm{~N} \mathrm{ha}^{-1}$ ) and $33 \mathrm{~kg} \mathrm{~K} \mathrm{ha}^{-1}$ as potassium chloride was broadcast the prior fall by the cooperating farmer. In Kansas in 2007 and 2008, 10 $\mathrm{kg} \mathrm{P} \mathrm{ha}{ }^{-1}$ and in $2009,25 \mathrm{~kg} \mathrm{P} \mathrm{ha}^{-1}$ was applied at planting as a surface dribble starter of 
ammonium polyphosphate. In all years at the Kansas sites, the ammonium polyphosphate application at planting was adjusted to a total of $20 \mathrm{~kg} \mathrm{~N} \mathrm{ha}^{-1}$ with urea-ammonium nitrate. The AA rates were not adjusted for $\mathrm{N}$ applied in the starter or $\mathrm{P}$ fertilizers. At the Illinois sites, no fertilizer was applied prior to planting as soil nutrient levels were considered adequate.

At all sites, soybean (Glycine max. L. Merr.) was the previous crop. There was no tillage done before or after AA application. Weeds were controlled using some combination of residual, soil applied herbicides, and glyphosate post emergence as needed. Anhydrous ammonia application dates, corn planting dates, and hybrids are summarized in Table 2. At all sites, hybrids were adapted to the geographic area and Bacillus thuringiensis (Bt) traits were used for insect control. No additional insecticides were applied. Seeding rates ranged from 59,300 to 86,500 seeds $\mathrm{ha}^{-1}$ in different years and sites, with the intent to plant near optimal seeding rates for the specific site; with actual rate therefore varying between sites and mainly between states (Table 2). Corn was planted in 76-cm width rows, with individual plots 4 rows wide by 30 to 70 $\mathrm{m}$ in length. A $15-$ to $40-\mathrm{m}$ border length was used to bring the tractor to desired speed and AA to desired flow rates prior to entering plots for treatment application.

\section{Anhydrous Ammonia Treatment Applications}

Treatments were arranged in a split-plot, randomized complete block, using a factorial design and four replications. The main plot was time of AA application, and the application method and $\mathrm{N}$ rate were randomized within the time of application main plot. The AA application timing was late fall after soil temperature was below $10^{\circ} \mathrm{C}$ at the $10-\mathrm{cm}$ depth, $\mathrm{SP} 7 \mathrm{~d}$ minimum prior to planting (7-14 d across sites and years), and SD at the V2 corn growth stage (Abendroth et al., 2011) (V2-V6 across sites and years). In 2007, only SP and SD applications were made due to study initiation in the spring of 2007. Actual application dates varied due to geographic location, 
soil moisture conditions, and corn growth, but were approximately early- to mid-Nov. for fall, mid-Apr. to mid-May for SP, and mid-June for SD. The N application rates were 0, 90, 135, 180, and $225 \mathrm{~kg} \mathrm{~N} \mathrm{ha}^{-1}$ for all fall and SP applications. In 2008 and 2009 at the Illinois and Iowa sites, the SD treatments had $20 \mathrm{~kg} \mathrm{~N} \mathrm{ha}^{-1}$ applied preplant or at planting as ammonium nitrate or ureaammonium nitrate solution, but the application at SD was adjusted accordingly to maintain a consistent rate across timings of application.

Anhydrous ammonia application rates were calibrated in set-length test areas immediately before application. Applicators were equipped with $454 \mathrm{~L}$ tanks and weigh systems so differential in AA tank weights were used for calibration. Ammonia rate and distribution control varied between years and sites, and included a Kontrol-Flo II controller, Equa-Flo distributor, and Sky-Trac GPS (Squibb-Taylor, Dallas, TX) in 2007 and 2008 at Illinois sites and 2007 in Iowa; and a Continental C-2500 Meter Matic (Continental $\mathrm{NH}_{3}$ Products, West Yorktown, TX) and Impellicone (CDS-John Blue Company, Huntsville, AL) flow divider all years at Kansas sites, 2009 in Illinois, and 2008 and 2009 at Iowa sites.

Two systems of AA placement into soil were used. One method was a newly developed proprietary opener system (John Deere, Waterloo, IA) designed to place AA at a shallow depth, with low soil disturbance, and at a high application speed (the HSLD system); and the other was a conventional-till knife injection system (the CTKI system) with covering disks, also supplied by John Deere, designed to place AA at a traditional depth and application speed. The HSLD is an integrated unit that consisted of a $56-\mathrm{cm}$ straight blade coulter set on a four degree angle, a 7$\mathrm{cm}$ wide depth gage wheel, an opener shoe with the AA outlet port behind the shoe (AA released from the bottom of the supply tube) and under a sealing wing, and two $30-\mathrm{cm}$ cast trailing closing wheels running on the soil surface, each angled in opposite directions with the first one 
including a notched blade protruding from the wheel (Picture 1). The HSLD opener system has been since modified and is commercially available on the John Deere $2510 \mathrm{H}^{\circledR}$ nutrient applicator. The CTKI consisted of a straight blade coulter for cutting surface residue, a forward swept knife with a leading shoe and the AA outlet ports (AA released from each side of the supply tube) behind and at the bottom of the knife, and two wavy coulters angled to provide surface soil coverage over the injection track (Picture 2).

Planned AA application depth and ground speed for the HSLD was $10 \mathrm{~cm}$ at all application timings and $16 \mathrm{~km} \mathrm{hr}^{-1}$ fall and SP, and $13 \mathrm{~km} \mathrm{hr}^{-1} \mathrm{SD}$; and for the CTKI was $18 \mathrm{~cm}$ and $10 \mathrm{~km}$ $\mathrm{hr}^{-1}$ at all application timings. Actual application depth and speed varied by site due to several factors, including soil conditions and tractor limitations; and were 10 to $13 \mathrm{~cm}$ and 13 to $16 \mathrm{~km}$ $\mathrm{hr}^{-1}$ with the HSLD, and 18 to $20 \mathrm{~cm}$ and 9 to $10 \mathrm{~km} \mathrm{hr}^{-1}$ with the CTKI. For fall and SP applications, the applicator had four of the HSLD or CTKI, set on 76-cm spacing. The injection tracks were oriented to be placed under future corn rows. This orientation with the corn rows was planned to provide the worst-case scenario for AA damage to corn seedlings and roots. For SD applications, the applicator had two of the HSLD or CTKI systems, set on 152-cm spacing, and with the injection tracks placed between every other row. With the SD applied between alternate rows, the $\mathrm{N}$ rate doubled per injection track. Each system was also run through the zero $\mathrm{N}$ rate plots at each application. During applications, observations were made for visual loss of ammonia, and after application visual damage to corn roots, seedlings, and plant vegetation.

\section{Corn Plant and Grain Measurements}

Corn plant population (PP) was counted at the V2 growth stage shortly before SD application to determine fall and SP AA application effects on plant establishment. All plants were counted 
in a 12-m marked length in each of the center two rows per plot. Since the seeding rate was different at each site, a relative plant population (RPP) was calculated with the population from all SD timing counts used as $100 \%$ since no SD treatments had yet been applied. At the Illinois and Iowa sites, plant height of 30 and 20 plants per plot, respectively, was measured approximately $14 \mathrm{~d}$ after SD application (V4 and V8 growth stages in Illinois and V4-V6 stages in Iowa) by measuring from the soil surface to the most extended (tallest) leaf tip.

As an estimate of mid-season plant $\mathrm{N}$ status, chlorophyll meter readings were collected using a Minolta SPAD-502 meter (Konica Minolta, Ramsey, NJ) at the V8 to V14 growth stages at Illinois and Iowa sites. The meter produces an output in SPAD units, which are correlated with leaf chlorophyll and $\mathrm{N}$ concentration (Schepers et al., 1992; Markwell et al., 1995). The chlorophyll meter readings were taken from the uppermost fully developed leaf (leaf with collar fully visible) on fifteen to twenty plants per plot, at a point one-half the distance from the leaf tip to the leaf base, and halfway between the leaf margin and midrib using the procedure described by Peterson et al. (1993). Due to the range of hybrids, sites, and years, relative chlorophyll meter (RCM) values for each plot were used in analyses instead of SPAD meter reading. The RCM values were calculated by dividing plot mean chlorophyll meter readings by the mean chlorophyll meter reading from the highest $\mathrm{N}$ rate for each application method and timing within a site, and then multiplied by 100 . Use of the RCM values provides an estimate of the presence or absence of corn $\mathrm{N}$ deficiency. Chlorophyll meter readings have been widely reported to be related to the N status of corn plants (Piekielek and Fox, 1992; Blackmer and Schepers, 1994; Piekielek et al., 1995; Fox et al., 2001) with RCM values at 95 to 97 indicating adequate N (critical or sufficiency levels) and less than those values indicating deficient N (Peterson et al., 1993; Blackmer and Schepers, 1995; Varvel et al., 1997; Hawkins et al., 2007). 
At the Iowa sites, the corn canopy biomass and growth response was measured with a Holland Scientific Crop Circle ACS-210 ${ }^{\mathrm{TM}}$ (Holland Scientific, Lincoln, NE) optical, active light canopy sensor on the same day as the chlorophyll meter measurements. The sensor was mounted on a mast, positioned between the center two plot rows, and carried by hand at $1.5 \mathrm{~m} \mathrm{~s}^{-1}$ and 0.60 to $0.90 \mathrm{~m}$ height above the crop canopy. Visible (VIS) and near infrared (NIR) reflectance values were recorded with a datalogger and used to calculate plot mean normalized difference vegetation index using the following equation:

$$
N D V I=\frac{\mathrm{NIR}-\mathrm{VIS}}{\mathrm{NIR}+\mathrm{VIS}}
$$

Corn GY was determined by either hand harvesting from the center two rows of each plot or by machine harvesting the entire center two rows using a plot combine. Reported GYs were adjusted to $155 \mathrm{~g} \mathrm{~kg}^{-1}$ moisture.

\section{Statistical Analyses and Calculations}

Analysis of variance (ANOVA) was conducted with the GLIMMIX procedure in SAS (SAS Institute, 2012) for each measurement, having main plots AA application timing and sub-plots a factorial arrangement of application method and $\mathrm{N}$ rate. Treatments were considered fixed and replicates random. For across site analyses, replicates, sites, years, and interactions with treatments were considered random. When significant, differences between main effects of application timing, method, and their interactions were determined with the PDIFF option in GLIMMIX $(P \leq 0.05)$. When the effect of $\mathrm{N}$ rate or $\mathrm{N}$ rate interaction with application timing and method were significant, linear, linear-plateau, quadratic, and quadratic-plateau regression models were fit using GLM and NLIN procedures of SAS. The model statistically significant ( $P$ $\leq 0.05)$ and with the largest coefficient of determination $\left(R^{2}\right)$ was selected. With GY, the fitted 
regression models were used to determine the maximum response and agronomic optimum $\mathrm{N}$ rate $(\mathrm{AONR})$.

\section{RESULTS}

\section{Climatic Conditions}

Mean monthly temperatures in the years of study were similar to long-term means at all sites (Appendix I). Total yearly and growing season precipitation varied due to geographic distribution of the study sites (Appendix II). The Illinois site in 2007 was relatively dry through the growing season, but in 2008 and 2009 had above normal precipitation, especially in 2008. At the Iowa sites in 2007 and 2008, repeated spring and early summer precipitation events resulted in wet soils and water ponding in some of the study areas. This caused poor corn plant population in one replicate each of those years, and therefore, only three replications were used in 2007 and 2008. In 2009, the Iowa site had below normal precipitation for most of the growing season. At the Kansas sites, growing season precipitation was below normal in 2007 and 2008, with 2009 receiving more normal precipitation. At the Kansas sites in 2008 and 2009, supplemental irrigation was applied as suggested using the KANSCHED irrigation scheduling program. No irrigation was applied at other sites.

\section{Corn Plant Measurements}

\section{Plant Population}

The statistical significance of AA application timing, method, and N rate on RPP (V2 growth stage) across all sites is given in Table 3. The PP measurements were taken before SD application, therefore, the RPP only include fall and SP applications. Across all sites, none of the application treatments had a significant effect on RPP (Tables 3 and 4), but site was 
significant $(P=0.005)$. Among sites within each state, AA application method had a significant effect on RPP in 2007 and 2009 at the Iowa sites, and the application method by timing interaction was significant in 2008 at the Illinois site (Table 5). No effect from AA application method on RPP occurred for the Kansas sites in any year. At the Iowa sites, application method was significant in 2007, and timing, $\mathrm{N}$ rate, and the timing by $\mathrm{N}$ rate interaction and the timing by application method interaction was significant in 2009 . There was no reduction in mean RPP with the CTKI, but the HSLD system produced an 11\% reduction in 2007 (Table 6). In 2009 at the Iowa site, the mean RPP was only $1 \%$ lower with the HSLD application (Table 7). The significant $\mathrm{N}$ rate by application timing interaction in 2009 resulted in a reduced RPP with the two highest $\mathrm{N}$ rates, predominantly due to reduced PP with the spring HSLD application. In 2008 in Illinois, the application timing by method interaction (Table 5) was explained by a reduction in RPP with the HSLD compared to the CTKI when AA was applied in the fall $(6 \%$ lower), but the opposite with the SP timing ( $4 \%$ higher with the HSLD) (data not shown). This application method effect on RPP was opposite of that found at the Iowa 2007 and 2009 sites.

\section{Plant Height}

Averaged across sites (measured each year at the Illinois and Iowa sites only), corn plant height (V4-V6 growth stages) was influenced by the timing by method interaction and application method by $\mathrm{N}$ rate interaction (Tables 3 and 8). The HSLD applications resulted in the mean corn height $3 \mathrm{~cm}$ shorter than with the CTKI. The HSLD application affected corn height with the SP application, but not with the fall application. The timing by application method interaction was explained by a reduction in plant height with HSLD relative to CTKI in the SP, but not the fall. This reduction in plant height with HSLD was likely related to seedling damage resulting from the higher $\mathrm{N}$ rates $(4 \%$ and $11 \%$ height reduction in highest two $\mathrm{N}$ rates 
compared to no fertilizer, respectively) (Table 8). These findings follow a similar trend as observed with RPP in Iowa where the HSLD system created root and seedling injury. The overall $\mathrm{N}$ rate effect was an increase in plant height in response to applied AA, but that response was negated at higher rates due to seedling damage and slower growth at the highest $\mathrm{N}$ rates with the SP HSLD application (Table 8). The reduced plant height with the SP HSLD application at the two highest $\mathrm{N}$ rates followed the same trend as found with RPP at the Iowa sites where shallow placed AA caused root and seedling growth injury.

\section{Plant Canopy and Nitrogen Status}

The chlorophyll meter readings were taken from just one leaf per plant, not the entire plant. Therefore, only $\mathrm{N}$ response (leaf greenness), and not plant canopy or biomass response to application method, would be reflected in RCM values. Leaf RCM values were influenced by timing, method, $\mathrm{N}$ rate, and the timing by $\mathrm{N}$ rate interaction (Table 3). Mean RCM values were lower with fall application than SP or SD (Table 9). This indicates less available N with the FA application. The HSLD applications had 2\% higher mean RCM value than the CTKI, reflecting lower RCM values with the fall CTKI application at the lowest two $\mathrm{N}$ rates. The timing by $\mathrm{N}$ rate interaction is shown in Fig. 1. The RCM values were lower with the fall application at the $90 \mathrm{~kg}$ $\mathrm{N} \mathrm{ha}^{-1}$ rate, but the similar with other $\mathrm{N}$ rates. An RCM value less than 97 has been shown in Iowa research to indicate $\mathrm{N}$ deficiency in corn (Hawkins et al., 2007). The RCM values with the SP and SD applications were at or above that critical level with 94 or more and 79 or more $\mathrm{kg} \mathrm{N}$ $\mathrm{ha}^{-1}$, respectively, but only with 144 or more $\mathrm{kg} \mathrm{N} \mathrm{ha}^{-1}$ with the fall application. These RCM differences indicate a potential for some $\mathrm{N}$ loss with the fall applications compared to SP and SD. The RCM values do not give any indication of damage from the HSLD as was found with RPP and plant height. 
Plant canopy sensing was conducted only at the Iowa sites. The NDVI values across the three years are given in Table 10. All main and interaction effects were significant (Table 3). There was an overall response to $\mathrm{N}$ rate, however, the NDVI values reached a peak at $100 \mathrm{~kg} \mathrm{~N}$ $\mathrm{ha}^{-1}$ and then declined at higher N rates with the SP HSLD application, but reached a plateau at $138 \mathrm{~kg} \mathrm{~N} \mathrm{ha}^{-1}$ with the CTKI and fall and SD HSLD applications (Fig. 2). The NDVI values recorded by the Crop Circle canopy sensor provide an indication of plant $\mathrm{N}$ status and crop canopy size. The reduction in NDVI values with the two highest $\mathrm{N}$ rates when applied with the HSLD would be a reflection of the reduced RPP and plant height found with those applications at the Iowa sites. The effect of AA damage on corn roots and early plant growth rate at the Iowa sites with the SP HSLD were evident in the reduced canopy NDVI values at the two highest $\mathrm{N}$ rates, and a reflection of reduced plant biomass rather than $\mathrm{N}$ deficiency. The NDVI values at the 180 and $235 \mathrm{~kg} \mathrm{~N} \mathrm{ha}^{-1}$ rates with the HSLD application were the same or lower as with the zero $\mathrm{N}$ rate. These low NDVI values indicate a small corn plant canopy, reduced leaf area, low plant density and biomass, and soil background effect on canopy sensing values.

\section{Corn Grain Yield}

Across all sites, corn GY was highly responsive to applied N rate (Table 11). There was a significant GY response to the interactions of timing and method with $\mathrm{N}$ rate (Table 3). Although the mean difference in GY among the three application times was not highly significant at the $P \leq 0.05$ level (Table 3), there was a mean $4 \%$ decrease in GY with the fall application compared to SP and SD (Table 11). The timing by $\mathrm{N}$ rate interaction indicated a reduction in GY with fall application in the 90 to $180 \mathrm{~kg} \mathrm{~N} \mathrm{ha}^{-1}$ rates (Fig. 3). Those lower yields with fall application would be the reason for the lower mean yield with fall application. The mean difference (across all N rates) in GY between HSLD and CTKI applications across all 
sites, while significant, was only $0.16 \mathrm{Mg} \mathrm{ha}^{-1}$ (Table 11). The difference in GY between application methods was from the seedling injury, expressed in the RPP and canopy sensing results, caused by the HSLD at the highest SP N rates (5.5\% lower GY at $225 \mathrm{~kg} \mathrm{~N} \mathrm{ha}^{-1}$ ) (Fig. 4). With the Iowa SP application data, GY was correlated (PROC CORR, SAS Institute, 2012 with PP and NDVI ( $\mathrm{r}=0.69$ and 0.86 , respectively; $P<0.001 ; \mathrm{n}=100$ ), which indicates the effect of HSLD AA application on seedling damage.

The mean across-site GY response to $\mathrm{N}$ rate, timing, and application method was evaluated by fitting regression models. Quadratic regressions were the best fitted model, $P \leq 0.01$. The SP and SD applications produced higher GY with lower $\mathrm{N}$ rates relative to the fall application (Fig. 3). The agronomic optimum $\mathrm{N}$ rate (AONR) and yield at AONR were similar for $\mathrm{SP}$ and $\mathrm{SD}$ applications with $11.87 \mathrm{Mg} \mathrm{ha}^{-1}$ at 167 for SP and $11.99 \mathrm{Mg} \mathrm{ha}^{-1}$ at $174 \mathrm{~kg} \mathrm{~N} \mathrm{ha}^{-1}$ for SD. The fall timing, however, had an AONR at $225 \mathrm{~kg} \mathrm{~N} \mathrm{ha}^{-1}$ with a GY of $11.73 \mathrm{Mg} \mathrm{ha}^{-1}$, resulting in a mean $55 \mathrm{~kg} \mathrm{~N} \mathrm{ha}^{-1}$ higher optimum $\mathrm{N}$ and $2 \%$ lower GY. The higher AONR and lower GY with the fall timing indicates lower efficiency of the fall AA application compared to SP and SD.

The mean GY response to N rates was a quadratic fit for both HSLD and CTKI methods (Fig 4). The GY decreased at the highest $\mathrm{N}$ rate with the HSLD application, but not the CTKI. This resulted in a higher GY at the AONR for the CTKI application than HSLD (11.95 $\mathrm{Mg} \mathrm{ha}^{-1}$ at 205 $\mathrm{kg} \mathrm{N} \mathrm{ha}^{-1}$ and $11.69 \mathrm{Mg} \mathrm{ha}^{-1}$ at $168 \mathrm{~kg} \mathrm{~N} \mathrm{ha}^{-1}$, respectively, for the CTKI and HSLD). The AONR was lower for the HSLD as a result of the GY decrease with the highest N rate, which reduced overall GY potential by $0.28 \mathrm{Mg} \mathrm{ha}^{-1}(2.3 \%)$. 


\section{DISCUSSION}

Corn response to $\mathrm{N}$ rate was generally positive, with an increase in plant growth and GY. However, there were situations where AA applied with the HSLD system resulted in reduced RPP, early growth, and crop canopy. This occurred in two years at Iowa sites when applied SP with $\mathrm{N}$ rates $\geq 180 \mathrm{~kg} \mathrm{~N} \mathrm{ha}^{-1}$. Plant damage did not occur with fall or SD applications at any $\mathrm{N}$ rate. Conditions that would lead to seedling damages are a small vertical distance from the point of AA placement to the seed, such as the 10-cm AA application depth with the HSLD and 5-cm seed depth. Depending on soil moisture and various soil physical properties, ammonia is often concentrated in zones from 5 to $20 \mathrm{~cm}$ wide (Blue and Eno, 1954; McDowell and Smith, 1958; Papendick and Parr, 1966). Higher $\mathrm{N}$ rates also result in a greater AA concentration in the injection band and result in more ammonia movement away from the band and toward the soil surface. Injected AA tends to move upward and laterally more than downward (Stanley and Smith, 1956). With the CTKI system, the apparent greater separation distance between the AA injection point $(20 \mathrm{~cm})$ and the corn seed eliminated the potential for AA damage to corn seedlings and roots. In our study, planting corn seed directly along or over the AA injection track provided the situation for the greatest chance of seedling damage from free ammonia. A solution to this potential problem would be to offset the corn row from the HSLD injection track, with the increased untreated soil between the seed and AA band buffering potential AA injury.

Deeper AA placement, as with the CTKI, would also help provide soil separation and reduce AA injury, as found in our study.

Various studies have reported injury to corn from AA application. Parr and Papendick (1966) reported corn root damage due to ammonia toxicity, which resulted in reduced GY. Colliver and Welch (1970) observed reduced PP, stunted early growth, and restricted seedling 
root development when a high rate of AA $\left(224 \mathrm{~kg} \mathrm{~N} \mathrm{ha}^{-1}\right)$ was applied at a $10-\mathrm{cm}$ depth immediately before planting (seed at a 5-cm depth). Increasing the time interval to 1 or $2 \mathrm{wk}$ between AA application and corn planting reduced the injury, but an increased application depth was more effective in reducing injury than the increased time interval (Colliver and Welch, 1970). In our study, seedling injury in Iowa was evident visually and in the lower measured PP as a result of the shallow HSLD AA placement at the highest two $\mathrm{N}$ rates $\left(180\right.$ and $225 \mathrm{~kg} \mathrm{~N} \mathrm{ha}^{-}$ ${ }^{1}$ ) when SP applied. No plant injury was observed with the fall or SD HSLD applications, or measured in the RPP or later with canopy sensing.

Depth of AA placement, $\mathrm{N}$ rate, and soil conditions affect AA retention and potential for ammonia movement and loss at application. Soil conditions include moisture level, texture, organic matter, and structure (Jackson and Chang, 1947; Blue and Eno, 1954; Nommik and Vahtras, 1982). Injection depth has a large influence on potential AA loss at application. In Iowa studies, increased loss of AA was reported with decreased injection depth regardless of the application speed (Abo-Abda, 1995) and when applied with a single-disc opener at a shallow 5 to $10 \mathrm{~cm}$ depth (Hanna et al., 2005); and in Kansas and Missouri studies AA loss increased with injection at depths $<10 \mathrm{~cm}$ (Wagner and Smith, 1958; Swart et al., 1971). Visible AA loss at application, as indicated by white water vapor puffing, occurred with some HSLD applications (visible at the point of release from the delivery tube before the closing wheels, with no loss visible after the closing wheels), especially at high $\mathrm{N}$ rates. Loss was not observed with CTKI applications at any $\mathrm{N}$ rate. Although conditions conducive to ammonia loss were not quantified in our study, they appeared to be related to a shallow injection point, high rate of AA, and soil physical structure that did not fracture within the operating depth of the HSLD, that is, the HSLD opener shoe sliced through the soil rather than fracturing soil. Potential for AA loss at 
application appeared to be related to the small size of the cavity created by the HSLD, the tendency for AA to move up the seam created by the disc blade and opener shoe, and a lower potential for AA to move laterally in soil that was less fractured and with a smaller cavity compared to the CTKI.

In 2007 and 2009 at the Iowa sites, there was visual root damage (necrotic tissue and reduced root growth), delayed emergence, and reduced seedling growth due to ammonia toxicity with the SP HSLD application at the highest three $\mathrm{N}$ rates. This observed damage (no damage ratings collected) produced the reduced RPP at the two Iowa sites, and effects on plant growth persisted into the growing season. There was no visible root damage observed with the CTKI from any application time or $\mathrm{N}$ rate. Apparently the shallow SP AA zone at the high $\mathrm{N}$ rates with the HSLD, and application relatively soon before planting, was too close to the planted corn seed and subsequent root growth at those Iowa site-years. The intended planting of the corn rows directly over previously applied preplant AA would result in the worst-case scenario for root damage. With the SD application, no change in RPP was measured with either the HSLD or CTKI (determined at the Illinois and Iowa sites, data not shown). This would be expected with the AA being placed at $38 \mathrm{~cm}$ from corn rows (mid inter-row) where depth of application would not have a differential impact on plant rooting.

Across all sites in the three states, fall AA application had an overall lower GY and higher AONR than SP and SD. Also, the GY N response was the same with SP and SD application. The lower GY and higher AONR with fall application was likely because of the long period between $\mathrm{N}$ application and uptake by the crop, with the increased chance of conversion of applied AA to nitrate and loss with wet conditions that often occur in the spring. Research comparing fall and SP AA application have found variable GY response, mainly due to 
differences in environment. In Ontario, Canada, fall application produced lower corn GY than SP or SD applications regardless of the $\mathrm{N}$ rate (from 56 to $224 \mathrm{~kg} \mathrm{~N} \mathrm{ha}^{-1}$ ) when applied to clay, clay loam, and silt loam soils (Stevenson and Baldwin, 1969). Reduced GY with fall application was greater on clay than loam textured soils. Welch et al. (1971) reported that a three-year average corn GY with fall application in central and northern Illinois was only $80 \%$ and $90 \%$ as effective as SP application at rates of 67 and $134 \mathrm{~kg} \mathrm{~N} \mathrm{ha}^{-1}$, respectively. Chalk et al. (1975), however, found no significant difference in corn GY between fall and SP application at medium $\left(112 \mathrm{~kg} \mathrm{~N} \mathrm{ha}^{-1}\right)$ and high $\left(336 \mathrm{~kg} \mathrm{~N} \mathrm{ha}^{-1}\right)$ rates of AA on a silt loam soil in Wisconsin.

\section{CONCLUSIONS}

There were positive plant and GY response to applied N with both the HSLD and CTKI application methods, and with fall, SP, and SD application timings. Fall application resulted in a higher AONR and lower GY than the SP and SD timings, and thus was the least efficient time of application. Corn response to applied $\mathrm{N}$ was the same with the SP and SD applications. High speed (13-16 $\left.\mathrm{km} \mathrm{hr}^{-1}\right)$ and shallow (10-13 $\mathrm{cm}$ depth) AA placement was successfully achieved with the HSLD applicator and corn response to applied $\mathrm{N}$ was similar with both application methods. However, with SP applications at some sites, especially at the two highest $\mathrm{N}$ rates of 180 and $225 \mathrm{~kg} \mathrm{~N} \mathrm{ha}^{-1}$, there were visual observations of ammonia loss during application with the HSLD and corn seedling root injury from ammonia toxicity which led to reduced PP, smaller plants, reduced canopy color (NDVI), and reduced GY. Seedling injury did not occur with any $\mathrm{N}$ rate or timing with the CTKI (18-20 depth and 9-10 $\mathrm{km} \mathrm{hr}^{-1}$ application).

Overall, results indicate that shallow placement of AA at high speed with the HSLD opener system can provide a viable substitute to traditional deeper knife injection with fall, SP, and SD applications, both with respect to retaining $\mathrm{N}$ in the soil and providing $\mathrm{N}$ supply to a corn crop; 
specifically, when soil conditions are conducive for proper HSLD operation and soil retention of AA. Anhydrous ammonia application with the HSLD, however, should be avoided where the AA may be injected directly under future corn rows and with high $\mathrm{N}$ rates. Global positioning equipped HSLD applicators and planters could be utilized to place SP applied AA away from future corn rows, or SD application made between corn rows, as a means to avoid seedling injury.

\section{ACKNOWLEDGMENTS}

We would like to thank John Deere and Company for partially funding this research and providing the AA application equipment. The authors acknowledge the assistance received from a number of persons involved with the study, including staff at the Iowa State University Agricultural Engineering and Agronomy Research Farms, University of Illinois Research and Education Center at Urbana, and Kansas State University Kansas River Valley Experiment Field, and on-farm cooperators for assistance with the study implementation and field operations. 


\section{REFERENCES}

Abendroth, L.J., R.W. Elmore, M.J. Boyer, and S.K. Marlay. 2011. Corn growth and development. PMR 1009. Iowa State Univ. Ext., Ames.

Abo-Abda, A. E. 1985. Field losses of anhydrous ammonia using a point injector fertilizer applicator. Unpublished M. S. thesis. Iowa State Univ., Ames, IA.

Blackmer, A.M., and C.A. Sanchez. 1988. Response of corn to nitrogen-15-labeled anhydrous ammonia with and without nitrapyrin in Iowa. Agron. J. 80:95-102.

Blackmer, T.M., and J.S. Schepers. 1994. Techniques for monitoring crop nitrogen status in corn. Commun. Soil Sci. Plant Anal. 25: 1791-1800.

Blackmer, T.M., and J.S. Schepers. 1995. Use of chlorophyll meter to monitor nitrogen status and schedule fertilization for corn. J. Prod. Agric. 8:56-60.

Blue, W.G., and C. F. Eno. 1954. Distribution and retention of anhydrous ammonia in sandy soils. Soil Sci. Soc. Am. Proc. 18:420-424.

Boswell, F.C. 1977. Seasonal anhydrous ammonia comparison for corn with and without a nitrification inhibitor. Agron. J. 69:103-106.

Brown, J.R. 1998. Recommended Chemical Soil Test Procedures for the North Central Region. North Central Regional Res. Publ. 221 (Rev.). Missouri Agric. Exp. Stn. SB 1001. Univ. of Missouri, Columbia, MO.

Bundy, L.G. 1986. Timing nitrogen applications to maximize fertilizer efficiency and crop response in conventional corn production. J. Fert. Issues. 3:99-106. 
Chalk, P.M., D.R. Keeney, and L.M. Walsh. 1975. Crop recovery and nitrification of fall and spring applied anhydrous ammonia. Agron. J. 67:33-37.

Colliver, G.W., and L.F. Welch. 1970. Toxicity of preplant anhydrous ammonia to germination and early growth of corn: I. Field studies. Agron. J. 62:341-346.

Cooke, I.J. 1962. Damage to plant roots caused by urea and anhydrous ammonia. Nature. 194:1262-1263.

Fernández, F.G., E.D. Nafziger, S.A. Ebelhar, and R.G. Hoeft. 2009. Managing nitrogen. Chapter 9 p. 113-132, In Illinois Agronomy Handbook 24th edition. Univ. of Illinois, Urbana, IL. http://extension.cropsci.illinois.edu/handbook/pdfs/chapter09.pdf (accessed February 28 2013).

Fox, R.H., W.P. Piekielek, and K.E. Macneal. 2001. Comparison of late-season diagnostic tests for predicting nitrogen status of corn. Agron. J. 93:590-597.

Fujinuma, R., R.T. Venterea, and C. Rosen. 2011. Broadcast urea reduces $\mathrm{N}_{2} \mathrm{O}$ but increases $\mathrm{NO}$ emissions compared with conventional and shallow-applied anhydrous ammonia in a coarsetextured soil. J. Environ. Qual. 40:1806-1815.

Hanna, H.M., P.M. Boyd, J.L. Baker, and T.S. Colvin. 2005. Anhydrous ammonia application losses using single-disc and knife fertilizer injectors. Appl. Eng. Agr. 21(4):573-578.

Hawkins, J.A., J.E. Sawyer, D.W. Barker, and J.P. Lundvall. 2007. Using relative chlorophyll meter values to determine nitrogen application rates for corn. Agron. J. 99:1034-1040.

Hendrickson, L.L., L.M. Walsh, and D.R. Keeney. 1978. Effectiveness of nitrapyrin in controlling nitrification of fall and spring applied anhydrous ammonia. Agron. J. 70:704-708. 
Hoeft, R.G. 1984. Current status of nitrification inhibitor use in U.S. agriculture. In: R.D. Hauck, editor, Nitrogen in Crop Production. Am. Soc. of Agron., Madison, WI, pp. 561-570.

Hawkins, J.A., J.E. Sawyer, D.W. Barker, and J.P. Lundvall. 2007. Using relative chlorophyll meter values to determine nitrogen application rates for corn. Agron. J. 99:1034-1040. doi:10.2134/agronj2006.0309.

IEM [Iowa Environmental Mesonet]. 2013. Daily summary data. Iowa Ag. Climate Network, Iowa State Univ., Ames. http://mesonet.agron.iastate.edu/agclimate/index.phtml (accessed 12 February 2013).

ISWS [Illinois State Water Survey]. 2013. Illinois Climate Network. Univ. of Illinois at UrbanaChampaign. http://www.isws.illinois.edu/warm/datatype.asp (accessed 29 August 2013).

Jackson, M.L., and S.C. Chang. 1947. Anhydrous ammonia retention by soils as influenced by depth of application, soil texture, moisture content, $\mathrm{pH}$ value, and tilth. Agron. J. 39:623633.

KSRE [K-State Research and Extension] 2013. Weather Data Library. Kansas State University. Manhattan, KS. http://wdl.agron.ksu.edu/ (accessed 1 April 2013).

Kyveryga, P.M., A.M. Blackmer, J.W. Ellsworth, and R. Isla. 2004. Soil pH effects on nitrification of fall-applied anhydrous ammonia. Soil Sci. Soc. Am. J. 68:545-551.

Markwell, J., J.C. Osterman, and J.L. Mitchell. 1995. Calibration of the Minolta SPAD-502 leaf chlorophyll meter. Photosynth. Res. 46:467-472. doi:10.1007/BF00032301

McDowell, L.L., and G.E. Smith. 1958. The retention and reactions of anhydrous ammonia on different soil types. Soil Sci. Soc. Amer. Proc. 22:38-42. 
Mengel, D.B., D.W. Nelson, and D.M. Huber. 1982. Placement of nitrogen fertilizers for no-till and conventional till corn. Agron. J. 74:515-518.

Miller, E., R.L. Nielsen, and J. Camberato. 2011. Response of corn to late-season nitrogen application. Corny News Network, Purdue Univ. Extension. West Lafayette, http://www.kingcorn.org/news/timeless/CornRespLateSeasonN.html (accessed 24 March 2013).

Nommik, H., and K. Vahtras. 1982. Retention and fixation of ammonium and ammonia in soils. Agron. Monog. 22:123-171.

Overdahl, C.J., and G.W. Rehm. 1990. Using anhydrous ammonia in Minnesota. Minnesota Extension Service. AG-FO-3073. Univ. of Minnesota, St. Paul, MN. http://conservancy.umn.edu/bitstream/93928/1/3073.pdf (accessed 3 March 2013).

Papendick, R.I., and J.F. Parr. 1966. Retention of anhydrous ammonia by soil: III. Dispensing apparatus and resulting ammonia distribution. Soil Sci. 102:193-201.

Parr, J.F., and R.I. Papendick. 1966. Retention of anhydrous ammonia by soil: II Effect of ammonia concentration and soil moisture. Soil Sci. 101:109-119.

Peterson, T.A., T.M. Blackmer, D.D. Francis, and J.S. Schepers. 1993. Using a chlorophyll meter to improve N management. Neb Guide G93-1171-1. Coop. Ext., Inst. Ag. Nat. Res., Univ. of Nebraska, Lincoln.

Piekielek, W.P., and R.H. Fox. 1992. Use of a chlorophyll meter to predict sidedress nitrogen requirements for maize. Agron. J. 84: 59-65.

Piekielek, W.P., R.H. Fox, J.D. Toth, and K.E. Macneal. 1995. Use of a chlorophyll meter at the early dent stage of corn to evaluate N sufficiency. Agron. J. 87:403-408. 
Randall, G.W., and J.E. Sawyer. 2008. Nitrogen application timing, forms and additives. p. 7385. In: G. Laing, editor, Final Report: Gulf Hypoxia and Local Water Quality Concerns Workshop. Upper Mississippi Sub-basin Hypoxia Nutrient Committee, Ames, IA. 26-28 Sep. 2005. ASABE, St. Joseph, MI.

Randall, G.W., and M.A. Schmitt. 1998. Advisability of fall-applying nitrogen. p. 90-96. In Proc. 1998 Wisconsin Fert., Aglime, and Pest Manage. Conf., Middleton, WI. 20 Jan. 1998. Univ. of Wisconsin, Madison.

Randall, G.W., J.A. Vetsch, and J.R. Huffman. 2003. Corn production on a subsurface-drained mollisol as affected by time of nitrogen application and nitrapyrin. Agron. J. 95:1213-1219.

SAS Institute. 2012. The SAS system for Windows. Release 9.3. SAS Inst., Cary, NC.

Schepers, J.S., D.D. Francis, M.F. Virgil, and F.E. Below. 1992. Comparisons of corn leaf nitrogen and chlorophyll meter readings. Commun. Soil Sci. Plant Anal. 23:2173-2187. doi:10.1080/00103629209368733

Schmitt, M.A., and G.W. Rehm. 1993. Soils, fertilizer and agricultural pesticides short course. University of Minnesota, Minneapolis, MN. p. 51-58.

Shi, W., and J.M. Norton. 2000. Effect of long-term, biennial, fall-applied anhydrous ammonia and nitrapyrin on soil nitrification. Soil Sci. Soc. Am. J. 64:228-234.

Smith, F.W. 1966. Application of ammonia. In: M.H. McVickar et al., editors, Agricultural Anhydrous Ammonia Technology and Use. Anhydrous Ammonia Institute, Memphis, TE, USA, Madison, WI, USA, AAI, ASA, SSSA. p. 101-114.

Stanley, F. A., and G. E. Smith. 1956. Effect of soil moisture and depth of application on retention of anhydrous ammonia. Soil Sci. Soc. Am. Proc. 20:557-561. 
Swart, C. L., L. S. Murphy, and C.W. Swallow. 1971. Retention patterns and effectiveness of anhydrous ammonia applied with a undercutting blade. Agron. J. 63.881-884.

Stevenson, C.K., and C.S. Baldwin. 1969. Effect of time and method of nitrogen application and source of nitrogen on the yield and nitrogen content of corn (Zea Mays L.). Agron. J. 61:381384.

Varvel, G.E., J.S. Schepers, and D.D. Francis. 1997. Ability for in-season correction of nitrogen deficiency in corn using chlorophyll meters. Soil Sci. Soc. Am. J. 61:1233-1239.

Wagner, G. H., and G. E. Smith. 1958. Nitrogen losses from soils fertilized with different nitrogen carriers. Soil Sci. 85(3):125-129.

Welch, L.F., D.L. Mulvaney, M.G. Oldham, L.V. Boone, and J.W. Pendleton. 1971. Corn yields with fall, spring, and sidedress nitrogen. Agron. J. 63:119-123.

Wood, C.W., D.W. Reeves, R.R. Duffield, and K.L. Edmisten. 1992. Field chlorophyll measurements for evaluation of corn nitrogen status. J. Plant Nutr. 15:487-500. 
Fig. 1. Interaction of $\mathrm{N}$ application timing by $\mathrm{N}$ rate for corn relative chlorophyll meter (RCM) values, across Illinois and Iowa sites, 2007-2009. The interaction is based on the statistical results in Table 3. Spring preplant (SP) and sidedress (SD).

Fig. 2. Interaction of $\mathrm{N}$ application timing by method by $\mathrm{N}$ rate for corn canopy normalized difference vegetative index, across Iowa sites, 2007-2009. The interaction is based on the statistical results in Table 3. The interaction is shown by the response for the spring preplant (SP) HSLD system high speed-low draft opener system (HSLD) application and the mean of all other timing and method applications.

Fig. 3. Interaction of $\mathrm{N}$ application timing by $\mathrm{N}$ rate for corn grain yield, across all sites, $2007-$ 2009. The interaction is based on the statistical results in Table 3. Open symbols represent means and closed symbols represent agronomic optimum N rate. Spring preplant (SP) and sidedress (SD).

Fig. 4. Interaction of $\mathrm{N}$ application method by $\mathrm{N}$ rate for corn grain yield, across all sites, 20072009. The interaction is based on the statistical results in Table 3. Open symbols represent means and closed symbols represent the agronomic optimum $\mathrm{N}$ rate. High speed-low draft opener system (HSLD) and conventional till knife injection system (CTKI).

Picture 1. The high speed-low draft opener system (HSLD).

Picture 2. The conventional till knife injection system (CTKI). 
Table 1. Site information and selected background soil test values for each site, 2007-2009.

\begin{tabular}{|c|c|c|c|c|c|c|c|c|c|c|c|}
\hline \multirow[b]{2}{*}{ Site } & \multirow[b]{2}{*}{ Town } & \multirow[b]{2}{*}{ State } & \multirow[b]{2}{*}{ Year } & \multicolumn{3}{|c|}{ Predominant soils } & \multicolumn{5}{|c|}{ Soil Tests } \\
\hline & & & & Series & Texture $\dagger$ & Classification & pH‡ & STP $\ddagger$ & STK $\ddagger$ & $\mathrm{NO}_{3}$-N§ & $\mathrm{OM}+$ \\
\hline & & & & & & & & & $-\mathrm{mg} \mathrm{k}$ & $1 \ldots$ & $\mathrm{g} \mathrm{kg}^{-1}$ \\
\hline 1 & Champaign & Illinois & 2007 & Flanagan & $\mathrm{Sl}$ & $\begin{array}{l}\text { fine, smectitic, mesic Aquic } \\
\text { Argiudolls }\end{array}$ & 5.6 & 45 & 198 & 7 & 36 \\
\hline 2 & Champaign & Illinois & 2008 & Flanagan & Sl & $\begin{array}{l}\text { fine, smectitic, mesic Aquic } \\
\text { Argiudolls }\end{array}$ & 6.0 & 26 & 160 & 5 & 32 \\
\hline 3 & Champaign & Illinois & 2009 & Flanagan & S1 & $\begin{array}{l}\text { fine, smectitic, mesic Aquic } \\
\text { Argiudolls }\end{array}$ & 6.1 & 19 & 191 & 6 & 36 \\
\hline 4 & Boone & Iowa & 2007 & $\begin{array}{l}\text { Clarion } \\
\text { Nicollet }\end{array}$ & $\mathrm{Sl}$ & $\begin{array}{l}\text { fine-silty, mixed, superactive, } \\
\text { mesic Typic Endoaquolls } \\
\text { fine-loamy, mixed, } \\
\text { superactive, mesic Typic } \\
\text { Hapludolls } \\
\text { fine-loamy, mixed, } \\
\text { superactive, mesic Aquic } \\
\text { Hapludolls }\end{array}$ & 6.6 & 31 & 177 & 5 & 43 \\
\hline 5 & Boone & Iowa & 2008 & Harps & $\mathrm{L}$ & $\begin{array}{l}\text { fine-loamy, mixed, } \\
\text { superactive, mesic Typic } \\
\text { Calciaquolls } \\
\text { fine-loamy, mixed }\end{array}$ & 7.6 & 13 & 182 & 14 & 82 \\
\hline 6 & Boone & Iowa & 2009 & Webster & Scl & $\begin{array}{l}\text { superactive, mesic Typic } \\
\text { Endoaquolls } \\
\text { fine-loamy, mixed, } \\
\text { superactive, mesic Typic } \\
\text { Hapludolls } \\
\text { fine-loamy, mixed, } \\
\text { superactive, mesic Aquic } \\
\text { Hapludolls }\end{array}$ & 6.7 & 16 & 179 & 6 & 45 \\
\hline
\end{tabular}




\begin{tabular}{|c|c|c|c|c|c|c|c|c|c|c|c|}
\hline 7 & Willard & Kansas & 2007 & Lady Smith & Scl & $\begin{array}{l}\text { fine, smectitic, mesic Pachic } \\
\text { Udertic Argiustolls }\end{array}$ & 6.1 & 15 & 200 & 8 & 12 \\
\hline 8 & Silver Lake & Kansas & 2008 & Rossville & $\mathrm{S} 1$ & $\begin{array}{l}\text { fine-silty, mixed, superactive, } \\
\text { mesic Cummulic Hapludolls }\end{array}$ & 7.2 & 12 & 335 & 5 & 19 \\
\hline 9 & Silver Lake & Kansas & 2009 & Rossville & S1 & $\begin{array}{l}\text { fine-silty, mixed, superactive, } \\
\text { mesic Cummulic Hapludolls }\end{array}$ & 6.9 & 13 & 397 & 4 & 19 \\
\hline
\end{tabular}

$\dagger$ L, loam; Scl, silty clay loam; S1, silt loam.

+ Soil sample before treatment application, 0-15 cm depth Iowa and Kansas and 0-20 cm depth Illinois. STP, soil test P; STK, soil test K; OM, soil organic matter.

$\S$ Soil $\mathrm{NO}_{3}-\mathrm{N}$ sample depth and timing: Illinois, 0-30 cm depth spring before treatment application; Iowa, 0-30 cm depth early June from control plots; Kansas, 0-60 cm spring (2007) or fall (2007 and 2008) before treatment application. 
Table 2. Anhydrous ammonia application date, corn planting date, hybrid, and seeding rate for each site.

\begin{tabular}{|c|c|c|c|c|c|c|}
\hline \multirow[b]{2}{*}{ Site } & \multicolumn{3}{|c|}{ Application date } & \multirow{2}{*}{$\begin{array}{c}\text { Corn planting } \\
\text { date }\end{array}$} & \multirow[b]{2}{*}{ Hybrid $\dagger$} & \multirow{2}{*}{$\begin{array}{l}\text { Seeding } \\
\text { rate }\left(\mathrm{ha}^{-1}\right)\end{array}$} \\
\hline & Fall & Spring preplant & Sidedress & & & \\
\hline 1 & $-t$ & 8 May 2007 & 13 June 2007 & 17 May 2007 & P 34N40 & 84000 \\
\hline 2 & 18 Nov. 2007 & 23 Apr. 2008 & 12 June 2008 & 30 May 2008 & Р $32 T 85$ & 84000 \\
\hline 3 & 10 Nov. 2008 & 30 May 2009 & 25 June 2009 & 5 June 2009 & P $32 T 85$ & 79100 \\
\hline 4 & - & 14 May 2007 & 11 June 2007 & 21 May 2007 & DK 61-69 & 73900 \\
\hline 5 & 31 Oct. 2007 & 30 Apr. 2008 & 18 June 2008 & 15 May 2008 & P 34A18 & 86500 \\
\hline 6 & 3 Nov. 2008 & 16 Apr. 2009 & 5 June 2009 & 5 May 2009 & DK 61-69 & 81500 \\
\hline 7 & - & 30 Apr. 2007 & 18 June 2007 & 14 May 2007 & GH 9006 & 59300 \\
\hline 8 & 17 Nov. 2007 & 15 Apr. 2008 & 16 June 2008 & 2 May 2008 & PH 7624 & 73100 \\
\hline 9 & 19 Nov. 2008 & 22 Apr. 2009 & 19 June 2009 & 11 May 2009 & PH 7624 & 78100 \\
\hline
\end{tabular}

$\dagger$ DK, DeKalb; GH, Golden harvest; P, Pioneer; PH, Producers hybrids.

$\$$ Anhydrous ammonia not applied fall 2007. 
Table 3. Statistical significance of the effect of anhydrous ammonia timing, application method, and $\mathrm{N}$ rate on relative plant population (RPP) across all sites, plant height and relative chlorophyll meter (RCM) values across Illinois and Iowa sites, canopy normalized difference vegetation index (NDVI) across Iowa sites, and corn grain yield (GY) across all sites, 2007-2009.

\begin{tabular}{lccccc}
\hline \multicolumn{1}{c}{ Source } & RPP & Plant height & RCM & NDVI & $\begin{array}{c}\text { Corn } \\
\text { GY }\end{array}$ \\
\hline Location & 0.005 & 0.240 & 0.802 & $-\dagger$ & 0.672 \\
Timing (T) & 0.680 & 0.770 & 0.047 & 0.009 & 0.065 \\
Method (M) & 0.466 & 0.005 & $<0.001$ & $<0.001$ & 0.031 \\
N rate (R) & 0.390 & 0.016 & $<0.001$ & $<0.001$ & $<0.001$ \\
Tx M & 0.740 & 0.009 & 0.281 & $<0.001$ & 0.088 \\
Tx R & 0.590 & 0.414 & 0.016 & 0.001 & $<0.001$ \\
M x R & 0.485 & 0.076 & 0.212 & $<0.001$ & 0.002 \\
Tx M x R & 0.505 & 0.202 & 0.806 & 0.001 & 0.566 \\
\hline
\end{tabular}

$\uparrow$ Canopy NDVI measured only at Iowa sites. 
Table 4. Effect of anhydrous ammonia timing, application method, and $\mathrm{N}$ rate on relative corn plant population before sidedress $\mathrm{N}$ application across all sites, 2007-2009.

\begin{tabular}{|c|c|c|c|c|c|c|c|c|c|}
\hline \multirow[b]{2}{*}{$\mathrm{N}$ rate } & \multicolumn{3}{|c|}{ Fall } & \multicolumn{3}{|c|}{ Spring preplant } & \multicolumn{2}{|c|}{ Method mean } & \multirow{2}{*}{$\begin{array}{l}\text { N rate } \\
\text { mean }\end{array}$} \\
\hline & HSLD† & CTKI† & Mean & HSLD & CTKI & Mean & HSLD & CTKI & \\
\hline \multicolumn{10}{|l|}{$\mathrm{kg} \mathrm{N} \mathrm{ha}^{-1}$} \\
\hline 0 & $100 \%$ & 100 & 100 & 102 & 101 & 101 & 101 & 100 & 101 \\
\hline 90 & 101 & 101 & 101 & 100 & 100 & 100 & 100 & 101 & 100 \\
\hline 135 & 99 & 99 & 99 & 100 & 101 & 100 & 100 & 100 & 100 \\
\hline 180 & 98 & 102 & 100 & 100 & 101 & 100 & 99 & 101 & 100 \\
\hline 225 & 100 & 99 & 100 & 99 & 99 & 99 & 99 & 99 & 99 \\
\hline Method mean & 100 & 100 & & 100 & 100 & & 100 & 100 & \\
\hline Timing mean & & & 100 & & & 100 & & & \\
\hline
\end{tabular}

$\dagger$ HSLD, high speed low draft opener system; CTKI, conventional till knife injection system.

$\$$ No treatments or interactions statistically significant $(P \leq 0.05)$. Statistical analysis provided in Table 3 . 
Table 5. Statistical significance of the effect of anhydrous ammonia timing, application method, and $\mathbf{N}$ rate on relative corn plant population before sidedress $\mathbf{N}$ application across sites within each location, 2007-2009.

\begin{tabular}{|c|c|c|c|c|c|c|c|c|c|}
\hline \multirow[b]{2}{*}{ Source } & \multicolumn{3}{|c|}{ Iowa } & \multicolumn{3}{|c|}{ Illinois } & \multicolumn{3}{|c|}{ Kansas } \\
\hline & 2007 & 2008 & 2009 & 2007 & 2008 & 2009 & 2007 & 2008 & 2009 \\
\hline & ------ & & & & $P>\mathrm{F}$ & & & & ----- \\
\hline Timing (T) & $-\dagger$ & 0.263 & 0.004 & - & 0.648 & 0.338 & - & 0.851 & 0.589 \\
\hline Method (M) & 0.015 & 0.293 & 0.014 & 0.559 & 0.703 & 0.168 & 0.282 & 0.561 & 0.975 \\
\hline $\mathrm{N}$ rate $(\mathrm{R})$ & 0.253 & 0.294 & 0.004 & 0.865 & 0.512 & 0.569 & 0.387 & 0.319 & 0.668 \\
\hline $\mathrm{T} \times \mathrm{M}$ & - & 0.439 & 0.054 & - & 0.015 & 0.242 & - & 0.194 & 0.427 \\
\hline $\mathrm{T} \times \mathrm{R}$ & - & 0.946 & 0.021 & - & 0.311 & 0.305 & - & 0.092 & 0.888 \\
\hline$M \times R$ & 0.256 & 0.377 & 0.114 & 0.131 & 0.288 & 0.352 & 0.763 & 0.633 & 0.119 \\
\hline $\mathrm{T} \times \mathrm{M} \times \mathrm{R}$ & - & 0.051 & 0.292 & - & 0.323 & 0.052 & - & 0.822 & 0.788 \\
\hline
\end{tabular}

$\dagger$ Anhydrous ammonia not applied fall 2007 at each site and SD application excluded from analysis. 
Table 6. Effect of anhydrous ammonia timing, application method, and $\mathrm{N}$ rate on relative corn plant population before sidedress $\mathbf{N}$ application across Iowa sites in 2007.

\begin{tabular}{cccc}
\hline & \multicolumn{3}{c}{ Spring preplant } \\
\cline { 2 - 4 } N rate & HSLD $\dagger$ & CTKI & Mean \\
\hline $\mathrm{kg} \mathrm{N} \mathrm{ha}^{-1}$ & 92 & 99 & 96 \\
0 & 99 & 97 & 98 \\
90 & 96 & 100 & 98 \\
135 & 86 & 104 & 95 \\
180 & 73 & 98 & 86 \\
225 & $89 \mathrm{~b} \ddagger$ & $100 \mathrm{a}$ & \\
\hline
\end{tabular}

$\dagger$ HSLD, high speed low draft opener system; CTKI, conventional till knife injection system.

$\$$ Letters indicate statistical difference at $P \leq 0.05$. No means separation shown if treatments or interactions not significantly different. Statistical analysis provided in Table 5. 
Table 7. Effect of anhydrous ammonia timing, application method, and $\mathrm{N}$ rate on relative corn plant population before sidedress $\mathbf{N}$ application across Iowa sites in 2009.

\begin{tabular}{|c|c|c|c|c|c|c|c|c|c|}
\hline \multirow[b]{2}{*}{$\mathrm{N}$ rate } & \multicolumn{3}{|c|}{ Fall } & \multicolumn{3}{|c|}{ Spring preplant } & \multicolumn{2}{|c|}{ Method mean } & \multirow{2}{*}{$\begin{array}{c}\mathbf{N} \text { rate } \\
\text { mean }\end{array}$} \\
\hline & HSLD $\dagger$ & CTKI† & Mean & HSLD & CTKI & Mean & HSLD & CTKI & \\
\hline \multicolumn{10}{|l|}{$\mathrm{kg} \mathrm{N} \mathrm{ha}^{-1}$} \\
\hline 0 & 101 & 102 & $101 \mathrm{a} \ddagger$ & 101 & 103 & $102 \mathrm{a}$ & 101 & 103 & 102 \\
\hline 90 & 101 & 102 & $102 \mathrm{a}$ & 100 & 101 & $100 \mathrm{a}$ & 100 & 102 & 101 \\
\hline 135 & 102 & 100 & $101 \mathrm{a}$ & 101 & 100 & $100 \mathrm{a}$ & 101 & 100 & 101 \\
\hline 180 & 101 & 103 & $102 \mathrm{a}$ & 98 & 102 & $100 b$ & 100 & 102 & 101 \\
\hline 225 & 101 & 101 & $101 \mathrm{a}$ & 93 & 99 & $96 b$ & 97 & 100 & 98 \\
\hline Method mean & 101 & 101 & & 99 & 101 & & $100 \mathrm{~b}$ & $101 \mathrm{a}$ & \\
\hline Timing mean & & & $101 \mathrm{a}$ & & & $100 \mathrm{~b}$ & & & \\
\hline
\end{tabular}


Table 8. Effect of anhydrous ammonia timing, application method, and $\mathbf{N}$ rate on corn plant height (V4-V8 growth stages) across Illinois and Iowa sites, 2007-2009.

\begin{tabular}{|c|c|c|c|c|c|c|c|c|c|}
\hline \multirow[b]{2}{*}{$\mathrm{N}$ rate } & \multicolumn{3}{|c|}{ Fall } & \multicolumn{3}{|c|}{ Spring preplant } & \multicolumn{2}{|c|}{ Method mean } & \multirow{2}{*}{$\begin{array}{l}\text { N rate } \\
\text { mean } \neq\end{array}$} \\
\hline & HSLD $†$ & CTKI† & Mean & HSLD & CTKI & Mean & HSLD & CTKI & \\
\hline $\mathrm{kg} \mathrm{N} \mathrm{ha}^{-1}$ & & & & & --- $\mathrm{cm}$ & & & & -- \\
\hline 0 & 85 & 82 & 83 & 82 & 81 & 81 & 83 & 81 & 82 \\
\hline 90 & 86 & 87 & 87 & 86 & 89 & 88 & 86 & 88 & 87 \\
\hline 135 & 83 & 87 & 85 & 85 & 88 & 87 & 84 & 88 & 86 \\
\hline 180 & 86 & 85 & 86 & 79 & 89 & 84 & 83 & 87 & 85 \\
\hline 225 & 84 & 85 & 85 & 73 & 87 & 80 & 78 & 86 & 82 \\
\hline Method mean & $85 \mathrm{a} \S$ & $85 a$ & & $81 b$ & $87 a$ & & $83 b$ & $86 a$ & \\
\hline Timing mean & & & 85 & & & 84 & & & \\
\hline
\end{tabular}

$\dagger$ HSLD, high speed low draft opener system; CTKI, conventional till knife injection system.

t The $\mathrm{N}$ rate main effect significant regression model is $y=82.1+0.083 x-0.000371 x^{2} ; \mathrm{R}^{2}=0.98, P>\mathrm{F}=$ 0.023 .

$\S$ Letters indicate statistical difference at $P \leq 0.05$. No means separation shown if treatments or interactions not significantly different. Statistical analysis provided in Table 3. 
Table 9. Effect of anhydrous ammonia timing, application method, and $\mathrm{N}$ rate on mid-vegetative corn leaf relative chlorophyll meter values across Illinois and Iowa sites, 2007-2009.

\begin{tabular}{|c|c|c|c|c|c|c|c|c|c|c|c|c|}
\hline \multirow[b]{2}{*}{$\mathbf{N}$ rate } & \multicolumn{3}{|c|}{ Fall } & \multicolumn{3}{|c|}{ Spring preplant } & \multicolumn{3}{|c|}{ Sidedress } & \multicolumn{2}{|c|}{ Method mean } & \multirow{2}{*}{$\begin{array}{c}\mathrm{N} \text { rate } \\
\text { mean }\end{array}$} \\
\hline & HSLD† & CTKI† & Mean & HSLD & CTKI & Mean & HSLD & CTKI & Mean & HSLD & CTKI & \\
\hline \multicolumn{13}{|l|}{$\mathrm{kg} \mathrm{N} \mathrm{ha}^{-1}$} \\
\hline 0 & 84 & 81 & 82 & 84 & 82 & 83 & 84 & 82 & 83 & 84 & 82 & 83 \\
\hline 90 & 94 & 90 & 92 & 98 & 97 & 97 & 100 & 96 & 98 & 98 & 94 & 96 \\
\hline 135 & 100 & 95 & 97 & 99 & 99 & 99 & 100 & 100 & 100 & 99 & 98 & 98 \\
\hline 180 & 100 & 98 & 99 & 102 & 99 & 101 & 100 & 98 & 99 & 101 & 99 & 100 \\
\hline 225 & 101 & 101 & 101 & 100 & 100 & 100 & 100 & 100 & 100 & 100 & 100 & 100 \\
\hline Method mean & 96 & 93 & & 96 & 95 & & 97 & 95 & & $96 a t$ & $94 b$ & \\
\hline Timing mean & & & $94 b$ & & & $96 a$ & & & $96 a$ & & & \\
\hline
\end{tabular}


Table 10. Effect of anhydrous ammonia timing, application method, and $\mathrm{N}$ rate on canopy normalized difference vegetation index at the corn mid-vegetative growth stage across Iowa sites, 2007-2009.

\begin{tabular}{|c|c|c|c|c|c|c|c|c|c|c|c|c|}
\hline \multirow[b]{2}{*}{$\mathrm{N}$ rate } & \multicolumn{3}{|c|}{ Fall } & \multicolumn{3}{|c|}{ Spring preplant } & \multicolumn{3}{|c|}{ Sidedress } & \multicolumn{2}{|c|}{ Method mean } & \multirow{2}{*}{$\begin{array}{l}\mathrm{N} \text { rate } \\
\text { mean }\end{array}$} \\
\hline & HSLD $†$ & CTKI† & Mean & HSLD & CTKI & Mean & HSLD & CTKI & Mean & HSLD & CTKI & \\
\hline \multicolumn{13}{|l|}{$\mathrm{kg} \mathrm{N} \mathrm{ha}^{-1}$} \\
\hline 0 & 0.687 & 0.687 & 0.687 & 0.671 & 0.682 & 0.676 & 0.677 & 0.675 & 0.676 & 0.678 & 0.681 & 0.680 \\
\hline 90 & 0.726 & 0.712 & 0.719 & 0.720 & 0.723 & 0.722 & 0.724 & 0.728 & 0.726 & 0.723 & 0.721 & 0.722 \\
\hline 135 & 0.727 & 0.713 & 0.720 & 0.715 & 0.729 & 0.722 & 0.728 & 0.731 & 0.730 & 0.723 & 0.724 & 0.724 \\
\hline 180 & 0.731 & 0.728 & 0.730 & 0.690 & 0.737 & 0.713 & 0.723 & 0.732 & 0.727 & 0.714 & 0.732 & 0.723 \\
\hline 225 & 0.723 & 0.728 & 0.726 & 0.643 & 0.734 & 0.688 & 0.730 & 0.731 & 0.731 & 0.699 & 0.731 & 0.715 \\
\hline Method mean & $0.719 \mathrm{a} \ddagger$ & $0.714 \mathrm{a}$ & & $0.688 b$ & $0.721 \mathrm{a}$ & & $0.716 \mathrm{a}$ & $0.720 \mathrm{a}$ & & $0.708 b$ & $0.718 \mathrm{a}$ & \\
\hline Timing mean & & & $0.716 \mathrm{a}$ & & & $0.704 b$ & & & $0.718 \mathrm{a}$ & & & \\
\hline
\end{tabular}

$\uparrow$ HSLD, high speed low draft opener system; CTKI, conventional till knife injection system.

$\$$ Letters indicate statistical difference at $P \leq 0.05$. No means separation shown if treatments or interactions not significantly different. Significant timing by method by N rate interaction shown in Fig. 2. Statistical analysis provided in Table 3. 
Table 11. Effect of anhydrous ammonia timing, application method, and $\mathrm{N}$ rate on corn grain yield across all sites, 2007-2009.

\begin{tabular}{|c|c|c|c|c|c|c|c|c|c|c|c|c|}
\hline \multirow[b]{2}{*}{$\mathrm{N}$ rate } & \multicolumn{3}{|c|}{ Fall } & \multicolumn{3}{|c|}{ Spring preplant } & \multicolumn{3}{|c|}{ Sidedress } & \multicolumn{2}{|c|}{ Method mean } & \multirow{2}{*}{$\begin{array}{l}\mathrm{N} \text { rate } \\
\text { mean }\end{array}$} \\
\hline & HSLD† & CTKI $†$ & Mean & HSLD & CTKI & Mean & HSLD & CTKI & Mean & HSLD & CTKI & \\
\hline $\mathrm{kg} \mathrm{N} \mathrm{ha}^{-1}$ & ------- & ---------- & -1---- & -------- & -------- & ---- M & $\mathrm{ha}^{-1}-$ & & & & & ---- \\
\hline 0 & 7.56 & 7.70 & 7.63 & 7.91 & 8.46 & 8.19 & 7.85 & 7.59 & 7.72 & 7.78 & 7.92 & 7.85 \\
\hline 90 & 10.56 & 9.94 & 10.25 & 11.12 & 11.12 & 11.12 & 11.12 & 10.96 & 11.04 & 10.93 & 10.67 & 10.80 \\
\hline 135 & 11.37 & 10.84 & 11.10 & 11.52 & 11.72 & 11.62 & 11.63 & 11.89 & 11.76 & 11.50 & 11.48 & 11.49 \\
\hline 180 & 11.20 & 11.54 & 11.37 & 11.80 & 12.17 & 11.98 & 11.83 & 12.01 & 11.92 & 11.61 & 11.90 & 11.76 \\
\hline 225 & 11.48 & 12.11 & 11.80 & 10.96 & 11.78 & 11.37 & 11.39 & 11.93 & 11.66 & 11.28 & 11.94 & 11.61 \\
\hline Method mean & 10.43 & 10.43 & & 10.66 & 11.05 & & 10.76 & 10.88 & & $10.62 \mathrm{bt}$ & $10.78 \mathrm{a}$ & \\
\hline Timing mean & & & 10.43 & & & 10.86 & & & 10.82 & & & \\
\hline
\end{tabular}


Appendix I. Long-term and mean monthly temperature for each site.

\begin{tabular}{|c|c|c|c|c|c|c|c|c|c|c|c|c|c|}
\hline Site & Year & Jan. & Feb. & Mar. & Apr. & May & Jun. & Jul. & Aug. & Sep. & Oct. & Nov. & Dec. \\
\hline 1 & 2007 & 0 & -6 & 9 & 11 & 21 & 24 & 24 & 25 & 21 & 15 & 6 & -1 \\
\hline 2 & 2008 & -3 & -3 & 4 & 11 & 15 & 23 & 24 & 23 & 20 & 13 & 4 & -3 \\
\hline 3 & 2009 & -6 & 0 & 7 & 11 & 17 & 23 & 21 & 21 & 19 & 10 & 8 & -18 \\
\hline Long- & $\mathrm{n}$ mean $\dagger$ & -4 & -1 & 5 & 11 & 17 & 22 & 24 & 23 & 19 & 12 & 5 & -1 \\
\hline 4 & 2007 & -7 & -9 & 6 & 8 & 18 & 22 & 24 & 24 & 18 & 13 & 2 & -6 \\
\hline 5 & 2008 & -9 & -8 & 0 & 8 & 15 & 21 & 23 & 21 & 17 & 11 & 2 & -8 \\
\hline 6 & 2009 & -10 & -3 & 3 & 9 & 16 & 21 & 20 & 20 & 18 & 7 & 7 & -7 \\
\hline Long & n mean & -6 & -4 & 3 & 10 & 16 & 21 & 23 & 22 & 18 & 11 & 3 & -4 \\
\hline 7 & 2007 & -1 & -1 & 12 & 11 & 20 & 23 & 26 & 28 & 21 & 15 & 6 & -2 \\
\hline 8 & 2008 & -2 & -2 & 6 & 11 & 18 & 24 & 26 & 24 & 19 & 13 & 7 & -1 \\
\hline 9 & 2009 & -2 & 3 & 7 & 12 & 19 & 24 & 23 & 23 & 19 & 10 & 9 & -3 \\
\hline Long- & n mean & -1 & 1 & 7 & 13 & 19 & 24 & 26 & 25 & 20 & 13 & 6 & 0 \\
\hline
\end{tabular}

$\dagger$ Long-term mean temperature data obtained from available 30 (IL sites 1-3), 27 (IA sites 4-6), and 28 (KS site 7-9) years of mean monthly temperature obtained from ISWS (2013), IEM (2013), and KSRE (2013), respectively. 
Appendix II. Precipitation for each site.

Precipit

Deviation from long-term mean precipitation $\$$

Calendar

Site Year ation $\dagger$ Jan. Feb. Mar. Apr. May Jun. Jul. Aug. Sep. Oct. Nov. Dec. year total

\begin{tabular}{|c|c|c|c|c|c|c|c|c|c|c|c|c|c|c|c|}
\hline 1 & 2007 & 455 & +39 & 0 & -33 & -38 & -82 & +36 & -21 & -88 & -24 & -6 & +25 & +5 & 838 \\
\hline 2 & 2008 & 820 & +13 & +103 & -3 & -46 & +27 & +26 & +82 & -93 & +118 & -1 & -49 & +40 & 1243 \\
\hline 3 & 2009 & 788 & -33 & -6 & -3 & +81 & +8 & +1 & +37 & +26 & -65 & +136 & +5 & -68 & 1141 \\
\hline 4 & 2007 & 643 & -2 & +34 & +18 & +47 & +30 & -78 & -52 & +68 & -37 & +49 & -39 & -18 & 803 \\
\hline 5 & 2008 & 829 & -13 & -19 & -39 & +25 & +64 & +112 & +81 & -54 & -7 & +33 & +14 & +8 & 988 \\
\hline 6 & 2009 & 330 & 0 & -19 & +48 & +11 & -19 & -74 & -116 & -95 & -71 & -42 & -39 & -18 & 348 \\
\hline 7 & 2007 & 509 & -12 & -13 & +11 & -23 & +83 & -8 & -26 & -75 & -39 & +48 & -35 & -4 & 661 \\
\hline 8 & 2008 & 495 & -12 & +13 & -19 & -18 & -32 & -3 & -5 & -77 & +63 & +29 & -22 & +1 & 674 \\
\hline 9 & 2009 & 634 & -16 & -27 & +13 & +32 & -68 & +49 & +71 & -11 & -40 & -14 & +9 & +3 & 757 \\
\hline
\end{tabular}

$\uparrow$ Total precipitation from March through September from nearby weather stations, obtained from ISWS (2013) for IL sites 1-3, IEM (2012) for IA sites 4-6, and KSRE (2013) for KS sites 7-9.

+ Deviation from the available 30 (IL sites 1-3), 27 (IA sites 4-6), and 28 (KS sites 7-9) years of mean monthly 
Fig. 1

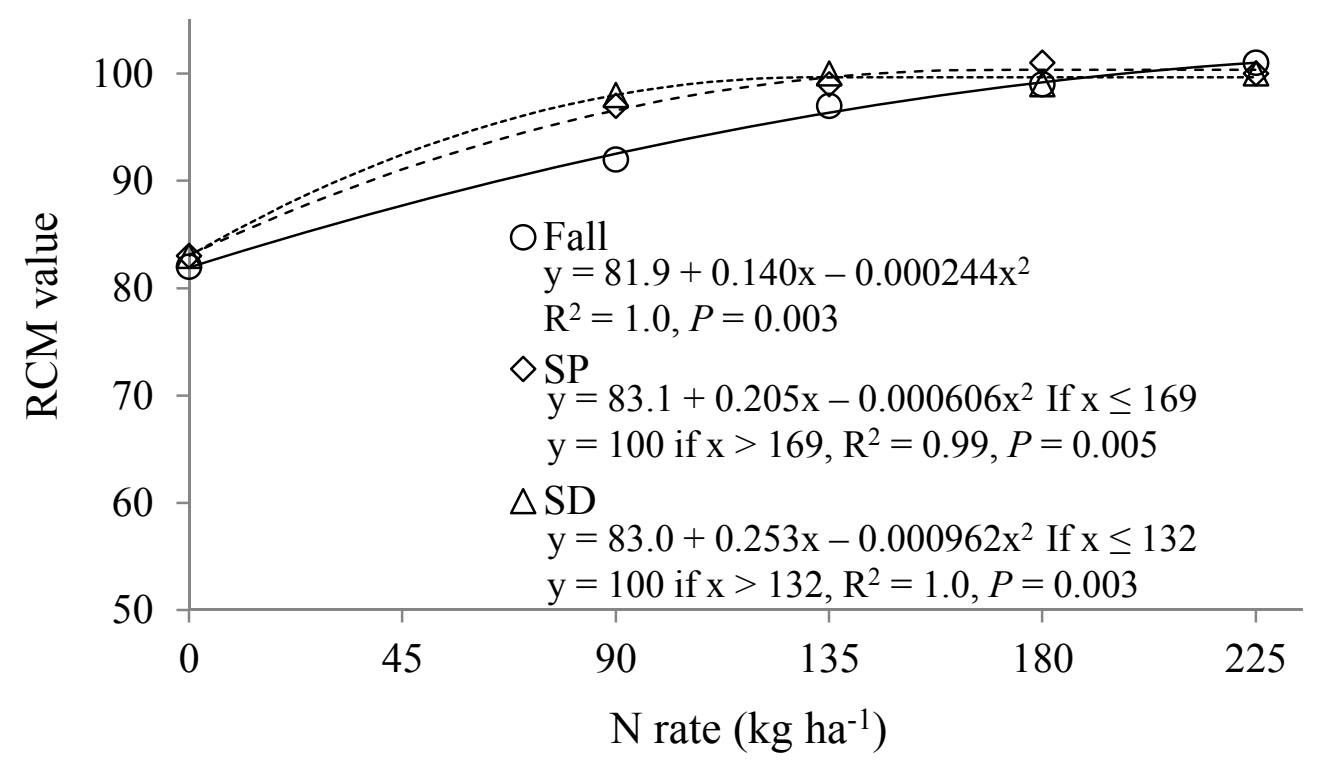


Fig. 2

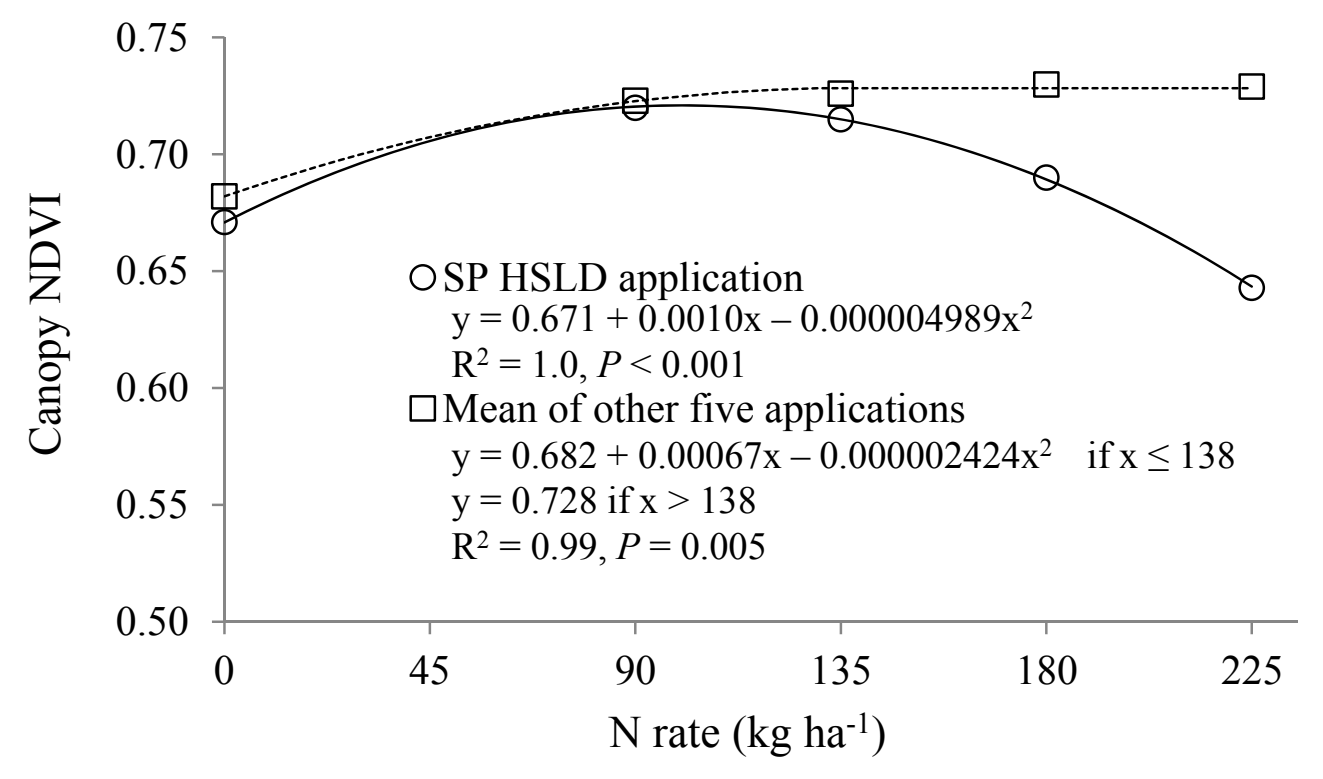


Fig. 3

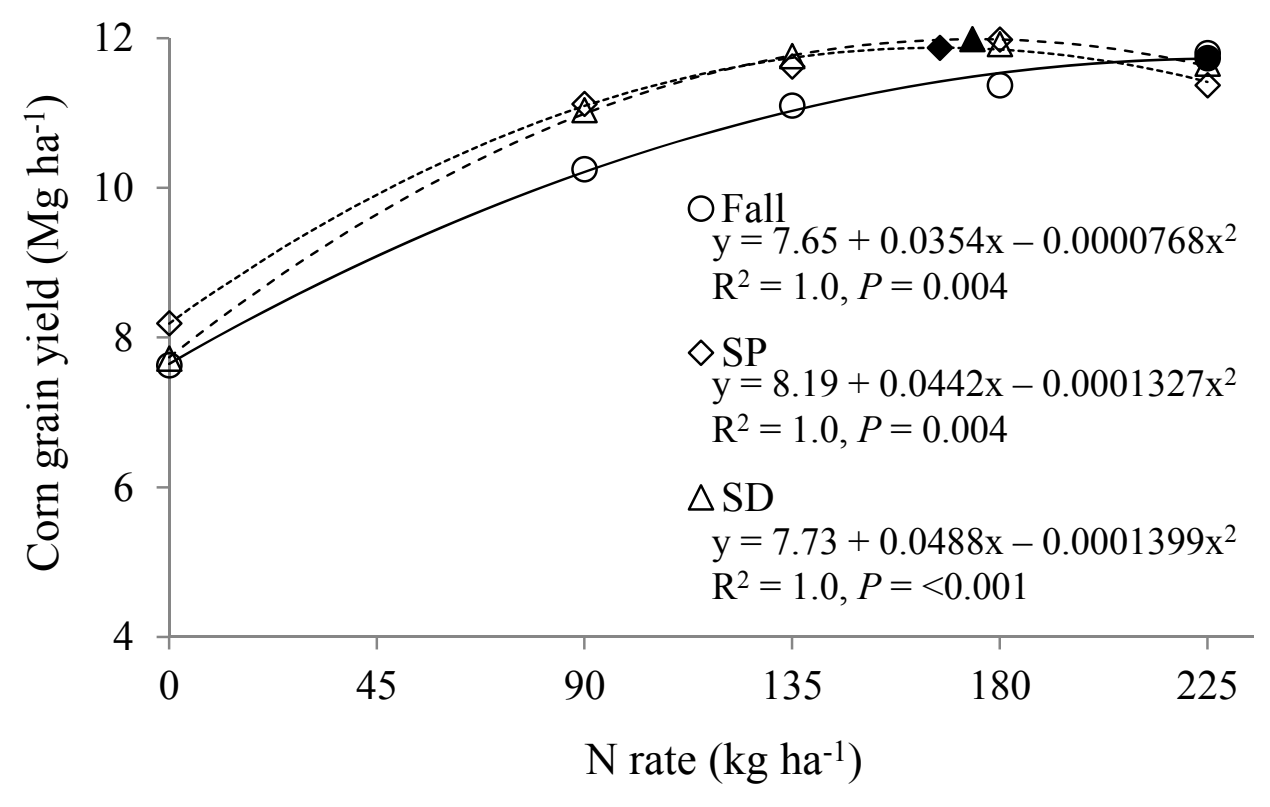


Fig. 4

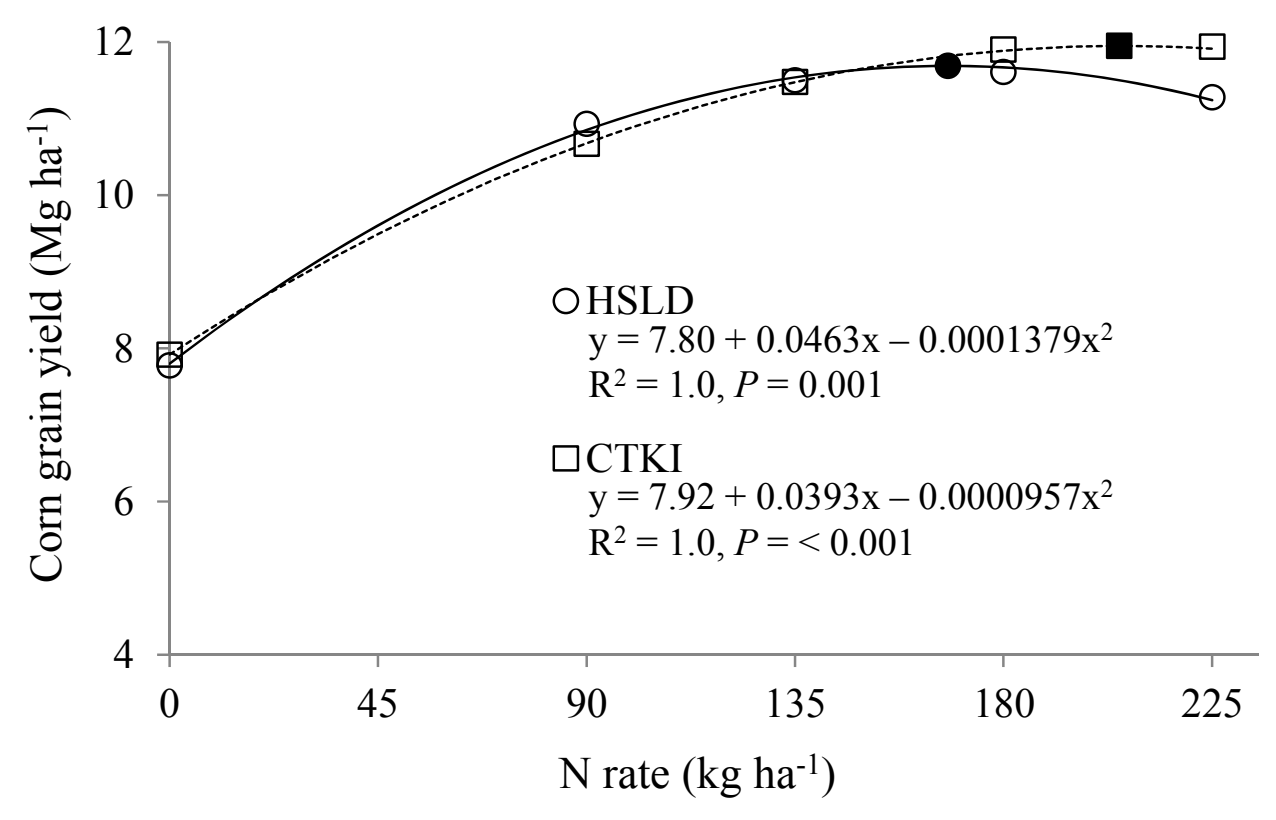


Picture 1

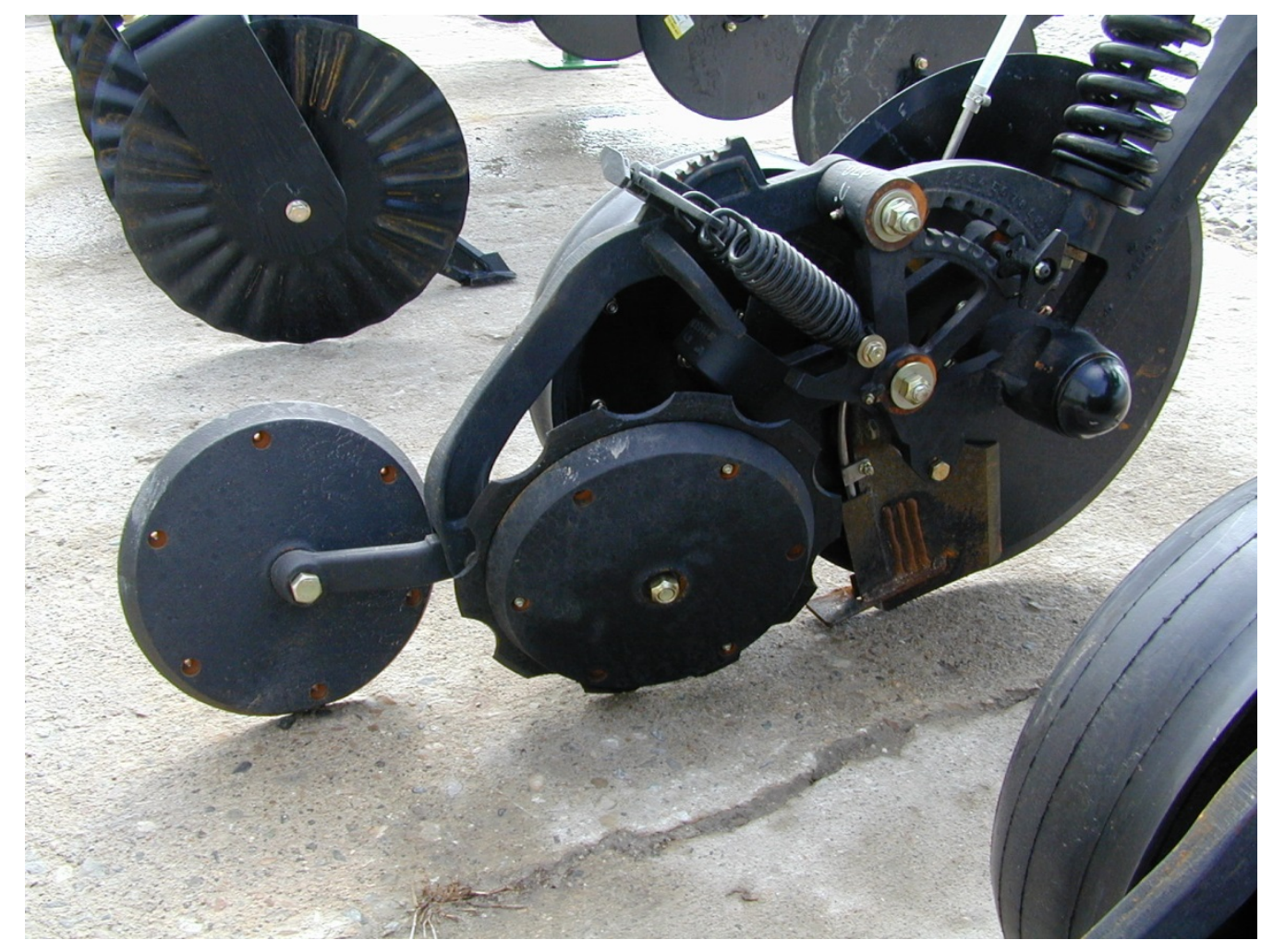


Picture 2

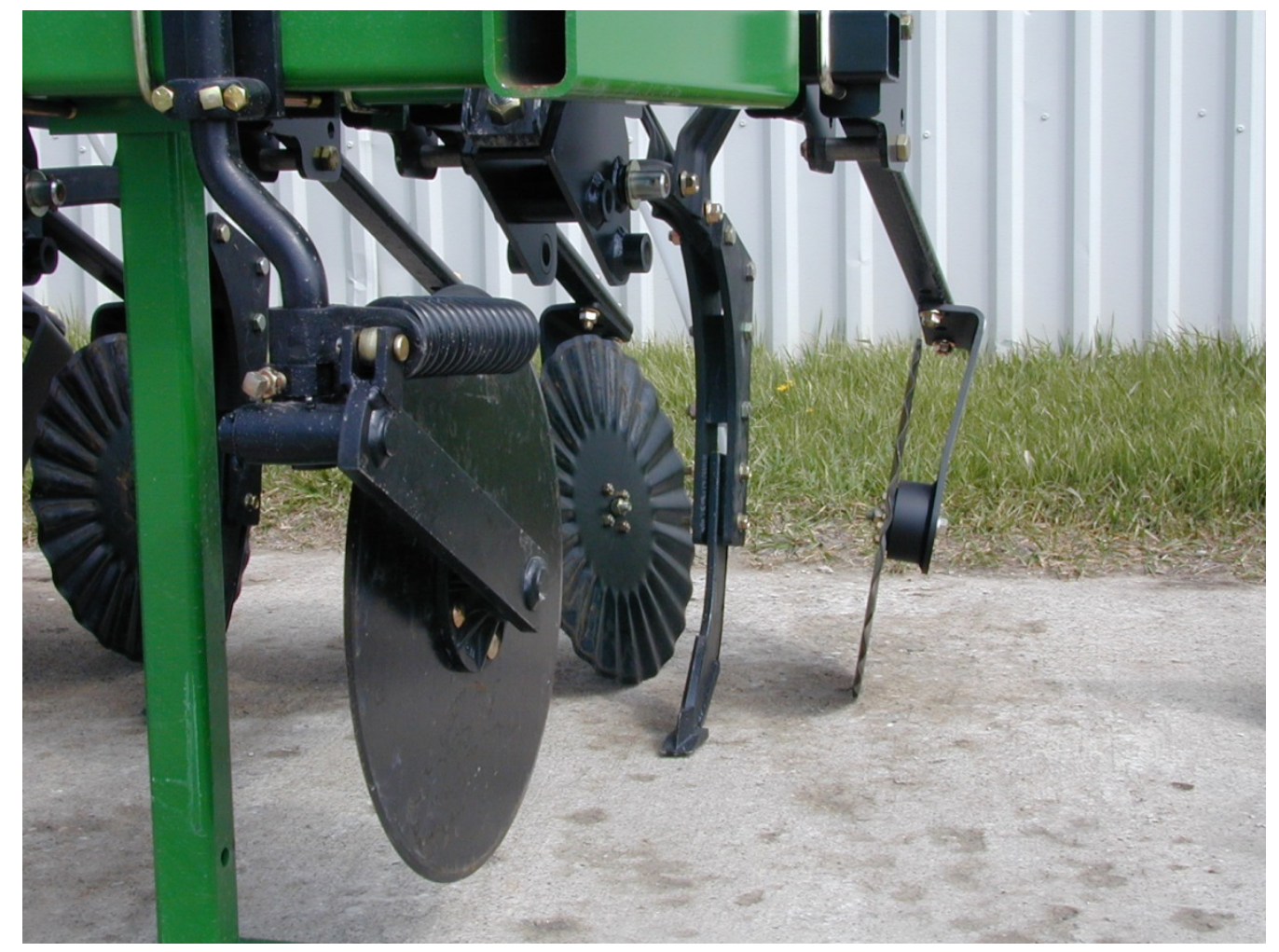

